
art, and so on.

"Portfolio of works" - refers to project, research, research papers, works in the field of

"Portfolio of reviews" - submission by the author (student-Creator of the work) of reviews of their work and reviews from other people. Examples can be: essays, letters of recommendation, a student's resume, or a review of an article.

The portfolio is made out in electronic and paper forms.

The paper version is collected in an individual folder, which records and accumulates the student's personal achievements in various activities (educational, industrial, scientific, creative, social, sports, etc.) for the entire period of study at the University. The paper version of the portfolio with the original documents is kept by the student. If desired, the student can add photos and video materials.

The electronic version is made using the PowerPoint program. The student independently records information about educational activities, participation in scientific, industrial activities, events, additional education, etc.

The documents application can contain copies of diplomas, certificates, certificates, certificates certified by the Deputy Director for Educational work, and scans of documents in electronic form.

The "works" application includes term papers, creative works, research papers, reports at scientific conferences,competitions, abstracts, printed works, etc.in electronic form-in word or RDF format.

The application "reviews" can contain characteristics from the places of practice, letters of recommendation, reviews of student achievements, thank-you letters, etc. [2].

The electronic format of the portfolio at the Nizhny Novgorod state University of engineering and Economics is uploaded by students independently in the student's personal account in the electronic information educational environment [3].

The portfolio is the same autobiography, but this document does not reflect the daily life of the student, but his creative and scientific achievements during the period of study in higher education. A detailed description significantly simplifies the job search, facilitates the interview, and allows you to feel like a complete unit of society[4].

$* * *$

1. The need for a portfolio for students. Access mode: http://studuslugi.ru/publishing/zachem_studentam_portfolio;

2. Требования к оформлению портфолио личных достижений. Access mode: https://docviewer.yandex.ru/view/418617607/?*=DswuMKXVGLjak6phb2Szji2RJed7InVybCI6InlhLW Rpc2stcHVibGljOi8vK2RtanlaVldRMG1hU1I1VGp6VmUyZGNzZFlkSEFIN3JtQkoxd25UZGpCVT0i LCJ0aXRsZSI6ItCi0YDQtdCx0L7QstCw0L3QuNGPINC6INC\%2B0YTQvtGA0LzQu9C10L3QuNGOI NC\%2F0L7RgNGC0YTQvtC70LjQvi5kb2N4IiwidWlkIjoiNDE4NjE3NjA3IiwieXUiOiIzMTQwNDc2N TAxNDc1NTAxNDMwIiwibm9pZnJhbWUiOmZhbHNILCJ0cyI6MTU0OTk4NjIxMzkxOH0\%3D;

3. Electronic information and educational environment of Nizhny Novgorod state engineering and economic university. Access mode: http://ngiei.mcdir.ru/;

4. Access mode: https://nsportal.ru/user/664283/page/portfolio-studenta-eto .

\title{
Bych E.I. \\ To the question of problems in online language teaching
}

Financial University under the Government of the Russian Federation

(Russia, Moscow)

doi: 10.18411/lj-05-2020-321

idsp: ljournal-05-2020-321

\section{Аннотация}

Статья посвящена организации онлайн-обучения в высшем учебном заведении. Отмечены проблемы в электронном дистанционном обучении. Рассматриваются возможности онлайн обучения. Особое внимание уделяется вопросу готовности 
преподавателей к использованию информационно-коммуникативной технологий в их профессиональной деятельности.

Ключевые слова: преподавание языков онлайн, электронное обучение, учебная среда, коммуникация, образовательные технологии

\section{Abstract}

The article is devoted to the organization of online education in higher education institution. Problems in electronic distance learning are noted. The possibilities of online learning are considered. Special attention is paid to the issue of teachers ' readiness to use information and communication technologies in their professional activities.

Keywords: online language teaching, e-learning, learning environment, communication, educational technologies

Presently, fundamental questions of online language learning in a higher school are being asked: In what ways can online teaching benefit the language learner most? How can online environments be designed, or redesigned, to suit the purposes of language learners? Finally, what does the language teacher need to know to become a successful online tutor? In other words, questions of pedagogy for online language teaching are becoming more and more actual. Discussions devoted to the topic ask for an appropriate online pedagogy, whether in collaborative settings, from a constructivist perspective, or in the context of intercultural communication. In all the areas, network computing and the ready availability of opportunities for communication outside the traditional language classroom have offered new potential and, thus, new challenges to research and pedagogy. The focus of research has shifted from quantitative to qualitative methods, from inside the classroom to online settings, and from the learning of language to the learning of culture. Scrutinizing in detail developments in one of these areas, S. Thorne outlines different models of "internet-mediated intercultural foreign language education." [3]. Collaboration and e-tandem are just two ways in which computer-mediated communication can be used to further intercultural competence through meaningful dialogue. As S. Thorne acknowledges, teacher intervention, planning, and organization clearly play a crucial role in the success of these collaborative learning endeavors, yet a pedagogic framework for them is still to be created.

The tutor role in higher school language education underwent considerable changes when approaches based on authentic communication and learner autonomy became pedagogical whitespace, if not outright demands. The appearance of generally available and reliable information and communication technology tools such as email, internet chat, or, more recently, instant messaging and audioconferencing has added to these trends, not a new dimension, but rather new attributes (ease and speed of access) and new quantities (number of Internet-based exchanges among people, the sheer mass of information available, access to native speakers and cultural information virtually across the globe).Since its beginnings, the use of computers in language teaching has moved from the initial computer as-tutor approach - based on a behaviorist learning model and reflected in repetitive drills-to communication and interaction via the computer. Ubiquitous connectivity among learners has allowed the move from this cognitive approach to learning to an integrative, sociocognitive approach combining traditional language skills such as listening, speaking, reading, and writing with electronic literacy skills such as learning to interact with others through the use of a variety of technological tools as an integral part of language teaching. Undoubtedly, network language-learning environments offering a variety of modes for communication and interaction have changed the face of the language classroom. These changes have had a profound and irreversible impact on language tutors and their roles - in the classroom and beyond. The enthusiasm for increased opportunities is reflected in a vast array of experimental, if often uncoordinated, uses of computers for language teaching. This is partly due to the fact that network environments that allow learners to communicate using the full 
range of multimodal forms are relatively new, but it is also a result of the on-going, fastmoving development of technologies and the multiplicity of the modes they afford. It has become apparent that enthusiasm alone will not necessarily lead to successful learning experiences. Information technology may provide us with the means of overstepping the boundaries between classroom and real life, making experiential learning a possibility. That is why we need teachers who can adapt or modify their students' language acquisition devices when necessary. There is, in other words, a growing consensus on the potential of developing an e-pedagogy for language learning, successful online tutors should know how to create a need in learners to adapt, stretch, and modify the means for communication and interaction available to them. Needless to say, the successful online tutor needs to

1. combine and adapt different roles, including those of teacher, administrator, trouble shooter, and colearner;

2. have recourse to different styles of teaching (e.g., cognitive, social, etc.); and

3. develop new e-teaching skills.

Research into online language pedagogy often comes from dedicated practitioners engaging in action research and motivated by a desire to improve practice in their field. One notable absence is the lack of new and innovative research into synchronous videoconferencing, because software development has not been as quick and reliable as anticipated. In some cases, a number of different roles (e.g., teacher, tutor, trainer, researcher, organizer, manager, course writer, etc.) are played by a single individual; in others, the authors are dedicated researchers. The insights from practitioners on how to make the best use of online contexts in their particular circumstances illustrate the multifarious nature of the terms "online teaching" and "on line learning" in the area of languages. The questions presented in the research show how much work there is still to be done in online language education and pedagogy.

A similar attempt to bridge the gap between technology and language pedagogy and to combine the development of both technical and pedagogical knowledge and competence forms the background into the online classroom. For pragmatic, financial, or pedagogic reasons, many institutions see blending as a solution to the practical problems of university teaching nowadays. For a variety of reasons, whether to increase access, student numbers, and the transferability of skills, or to give students a competitive edge in a global market, many language departments have incorporated online elements in their courses. Empowered to intervene actively in their course via the platform and encouraged to depart from suggested activities and move on to more self-directed work, learners at both ends of the capability spectrum manage successfully to become less dependent on their teacher. Their portfolio work tends to be more personalized, and they seem more creative in editing online material than those students who opt out of the program.

Often, however, tutors are faced with necessity to develop their e-teaching skills without sufficient institutional support. This problem is currently available.

On a personal and professional level as online coordinators, we still find that we have to struggle to reconcile the multifaceted daily demands of our job with our desire to carry out much-needed research in the field. There is a variety of ways to tackle the question of online pedagogy ranging from a qualitative "case study" approach based on deep personal insights via a theoretically based comparative study of different teaching and learning environments to a more general advocacy of pedagogic considerations as the basis for online teaching. Online teaching takes technical know-how, content that is planned from a pedagogic rather than a technological perspective, creative adaptation of skills and teaching styles, training of tutors to equip them for work in an environment where - as a result of an increasing rate of technological development - the goal posts are permanently shifting, and thus a willingness to change, adapt, question, and improve constantly. Despite the hope of some administrators that online language teaching would allow cuts in staff costs, the teacher is still very much part of 
the learning context; maybe not as a "guide on the side", but as a (co)designer of learning situations, mediator, and colearner in the search for information, the construction of knowledge, the development of competences, and the creation of opportunities for real and meaningful communication.

While we continue to develop and explore new ways of using online media, "teaching is indeed learning," and it will probably take a little longer to establish not only what it takes to teach online but also how we learn to teach online. Some of the challenges that lie ahead of us are: 1. multimodality and new literacies, 2. open source/open content, and 3. online tutor training on a larger scale. The increasing convergence of technologies makes new and different cognitive demands on tutors and learners. Open source/open content make it all the more important to think of delivery as well as content, of pedagogy as well as affordances, and of teachers (virtual or real) as well as materials. Open content will only become relevant when what is offered is pedagogically prepared material rather than a haphazard collection of lecture notes. On the other hand, learning activities prepared for one cultural context might have to be re-thought or re-presented for the global audience of open accessibility in order to meet culturally diverse learners' styles and needs. Language professionals are ideally placed for this task of localizing. Finally, online language teacher training is already gaining prominence, funding. It is likely that investigations of online teaching and online tutor skills similarly rely on enthusiastic teachers prepared to experiment with and reflect on their online teaching practice and its challenges. While we have presented here a range of views on the tasks and challenges of online pedagogy, a systematic overview of teacher training methods and reflective practice in online language teaching, a "How do we learn to teach online" collection might be the next step that is needed to carry this endeavor forward.

1. Felix, U. (2005). E-learning pedagogy in the third millennium: the need for combining social and cognitive constructivist approaches. ReCALL,17(1), 85-100 p.

2. Hampel, R., \& Stickler, U. (2015). New skills for new classrooms: Training tutors to teach languages online. Computer Assisted Language, 18 (4), 311-326 p.

3. Thorne, S. L. (2015). Internet-mediated intercultural foreign language education: Approaches, pedagogy, and research, 31, 51-71p.

\section{Kramarenko L.V. \\ Social service as a basis of pedagogical practice of future social teachers (on the example of Yalta)}

Humanitarian and pedagogical academy (branch) of the Federal state autonomous educational institution of higher education "Crimean federal university named after V.I.

Vernadsky»

(Russia, Yalta)

doi: $10.18411 / \mathrm{j}-05-2020-322$

idsp: ljournal-05-2020-322

\section{Abstract}

The article analyzes legislative regulation and a scientific approach to studying the problems of centers of social services for families, children and youth. The experience of centers for the organization and conduct of undergraduate teaching practice by future social educators is considered. The features of the formation of professional competence of future specialists on the basis of the students' practical activities on the basis of the centers are investigated. Actual directions of researching the centers' positive experience in preparing future social educators in working with needy categories of the population are proposed.

Key words: teaching practice; professional competence; social service; social teacher; subject of social work. 